\title{
Penyelenggaraan E-government di Kabupaten Bandung Sebagai Upaya Meningkatkan Kualitas Pelayanan Publik
}

\author{
${ }^{1}$ Diki Suherman \\ ${ }^{1}$ Universitas Padjadjaran, Indonesia; dikisuherman44@gmail.com
}

\begin{abstract}
The implementation of e-government in Bandung Regency still encounters several problems, namely inadequate telecommunications infrastructure. The theory used is that according to (Indrajit, 2004) there are three elements to implement the concept of e-government, namely: Support, Capacity and Value. The purpose of this study is to describe the implementation of egovernment in Bandung Regency as an effort to improve the quality of public services. The research method used is descriptive qualitative approach, with data collection and the techniques used are literature studies sourced from a number of articles in journals, books, regulations, information media content. The results show that the implementation of e-government in Bandung Regency is still in the development stage which is not yet massive, this can be seen from the limitations of technology supporting infrastructure and the quality of resources in the technology sector which is still lacking. The conclusion is the element of support, has support from government officials in Bandung regency to implement the implementation of e-government in the field of Communication and Information. In the capacity element, the infrastructure of Bandung Regency is still experiencing shortcomings in the implementation of e-government because the infrastructure development process is carried out in stages. Meanwhile, human resources in Bandung Regency are still lacking in the field of technology. In the value element, application utilization, Bandung Regency has implemented several internet-based applications to support public services and the use of information data that can be accessed on a single data portal.
\end{abstract}

Keywords: E-Government, Local Government, Public Service, Continuous Improvement.

\section{Pendahuluan}

Teknologi memiliki perananan penting terutama teknologi informasi dan komunikasi sebagai sarana interaksi untuk mendapatkan berbagai informasi demi penunjang kelancaran aktivitas / kegiatan yang dilakukan terutama pada instansi pemerintahan yang memberikan dampak pada reformasi birokrasi yang mampu membuat kinerja organisasi lebih efektif, efisien, dan kompetitif (Oktari \& Nasir, 2011).

Diterapkannya penggunaan teknologi informasi dan komunikasi di dalam instansi pemerintahan sebagai upaya untuk memberikan pelayanan publik merupakan hal sangatlah penting untuk dilakukan, karena dengan adanya bantuan teknologi dan informasi membantu proses penyelenggaraan yang cepat dan mudah serta tidak terbatas dengan jarak dan waktu(Sari \& Winarno, 2012). Maka berkenaan dengan hal terebut dikeluarkannya peraturan perundangundangan yang teruang di dalam Instruksi Presiden nomor 3 Tahun 2003 tentang Kebijakan dan Strategi Nasional Pengembangan e-Governmet, dalam aturan tersebut menyatakan bahwa dalam rangka untuk meningkatkan kualitas layanan publik untuk itu diperlukannya suatu tatakelola sistem manajemen dan proses kerja tang ada di lingkungan pemerintahan yang dilakukan dengan mengoptimalkan pemanfaatan teknologi informasi yang menunjang pelayanan publik berbasis 
digital, sehingga pelayanan publik melalui teknologi informasi yang disampaikan kepada masyarakat umum dilakukan lebih dengan cepat (Indonesia, 2003).

E-Government merupakan suata teknologi informasi yang digunakan oleh lemabaga pemerintahan yang membantu pemerintah untuk mentransformasikan hubungan antara pemerintah dengan masyarakat secara umum. Selain itu juga membangun hubungan pula dengan kegiatan bisnis dan pihak yang memiliki berkepentingan lainnya(Napitupulu, 2015). Di dalam pelaksanaanya, e-government memerlukan dan menggunakan akses internet sebagai sumber utama untuk membantu melaksanakan urusan pemerintahan dan penyediaan layanan publik sebagai upaya untuk lebih baik yang berorientasi pada pelayanan publik kepada masyarakat umum, serta membantu dalam memberikan pelayanan transparan dan memuaskan bagi masyarakat yang mendapatkannya (Praditya, 2014).

Pemerintahan Daerah Kabupaten Bandung merupakan salah satu instansi yang menerapkan E-Government untuk menunjang aktivitas pemerintahan dalam melakukan pelayanan publik, secara kelembagaan E-Government ini di kelola oleh Badan Arsip Perpustakaan dan Pengembangan Sistem Informasi (BAPAPSI), yang memiliki cangkupan dalam hal ; aplikasi dalam pengelolaan website, pengelolaan pelayanan publik, dan manajerial urusan kepemerintahan. Adanya penerapkan sistem informasi dan komunikasi sebagai sarana berinteraksi dengan masyarakat banyak/publik, yang dapat berlangsung dengan cepat tanpa harus bertatapan langsung. Penyelenggaraan e-government di Kabupaten Bandung tercantum dalam Peraturan Bupati Bandung Nomor 16 Tahun 2016 Tentang Kebijakan Umum Penyelenggaraan E-Government Di Lingkungan Pemerintah Kabupaten Bandung yang memiliki tujuan supaya penyelenggaraan e-government dilingkup pemerintahan Kabupaten Bandung yang teraraah dan bisa berjalan secara efektif serta efesien. Setelah diterbitkannya Peraturan Daerah Nomor 12 Tahun 2016 tentang Pembentukan dan Susunan Perangkat Daerah Kabupaten Bandung maka pada tahun 2017 dalam urusan kearsipan dan perpustakaan menjadi kewenangan Dinas Perpustakaan dan Kearsipan (DISPUSIP), sedangkan dalam urusan pengelolaan komunikasi publik, informatika, statistik dan persandian merupakan kewenangan dari Dinas Komunikasi dan komunikasi (DISKOMINFO).

Namun demikian dalam penyelenggaraan pemerintah berbasis digital atau secara online ternyata masih ditemui beberapa masalah. Seperti halnya, infrastruktur telekomunikasi yang belum memadainya terkhusus di beberapa kecamatan seperti: Rancabali, Kertasari, Pacet dan Arjasari. Adapun masalah yang menjadi kendala lainnya yang ditemui yakni beberapa aplikasi layanan publik belum terintegrasi secara menyeluruh. Selain itu fakor Sumber Daya Manusia/ SDM di bidang Teknologi Informasi dan Komunikasi/ TIK belum optimal di Kabupaten Bandung (bandungkab.go.id, 2016).

Penyelenggaraan e-government di Kabupaten Bandung dipilih untuk dijadikan kajian penelitian, karena sejauh ini belum ada penelitian yang secara pterperinci membahas tentang egovernment di Kabupaten Bandung, maka penulis tertarik untuk menelitinya. Adapun penelitian terdahulu yang berkaitan dengan e-government yakni oleh (Heryana, 2013) yang berjudul Pengaruh Penerapan E-Government Terhadap Pelaksanaan Tata Kelola Pemerintah Di Pemerintah Kabupaten Cianjur, dari penelitian yang dilakukan menunjukkan bahwa penerapan egovernment pada sebagian besar Dinas, Instansi dan Perkantoran di Kabupaten Cianjur berpengaruh sebesar 78,5\% terhadap pelaksanaan tata kelola Dinas, Instansi dan Perkantoran di Kabupaten Cianjur. Sedangkan 21,5\% sisanya merupakan pengaruh dari faktor lain di luar egovernment. Adapun yang lainnya dilakukan oleh (Aprianty, 2016) yang berjudul Penerapan Kebijakan E-Government dalam Peningkatan Mutu Pelayanan Publik di Kantor Kecamatan Sambutan Kota Samarinda, Dari hasil penelitian ditemukan bahwa Penerapankebijakan eGovernment dalam peningkatan mutu pelayanan publik di kantor kecamatan Sambutan kota 
Samarinda mulai mengalami perubahan pada pelayanan prima walaupun masih ada terdapat beberapa kekurangan yakni terbatasnya sumber daya yang dimiliki, kurangnya sosialisasi kebijakan kepada masyarakat, dan miskomunikasi antara pimpinan dan pegawai, yang membedakan dengan yang sedang dilakukan oleh penulis adala objek penelitian dengan teori yang digunakan oleh penulis adalah menurut (Indrajit, 2004) ada tiga elemen untuk menerapkan konsep e-government yaitu: Support, Capacity dan Value.

Maka itu tujuan dari penelitian ini yaitu untuk memaparkan penyelenggaraan egovernment di Kabupaten Bandung sebagai upaya untuk meningkatkan kualitas pelayanan publik. Permasalah ini perlu diteliti dan dipelajari lanjut karena sangat penting untuk mengetahui sejauh mana ketepatan kebijakan tersebut dilakukan dan dampak dari kebijakan tersebut terhadap publik.

\section{Metode Penelitian}

Dalam metode penelitian ini, pendekatan yang digunakan dalam penelitian adalah kualitatif. Hal ini disebabkan oleh alur penelitian dari umum ke khusus, maksudnya ialah bahwa penelitian ini berawal dari hasil pengamatan terhadap fenomena yang ada di lapangan, yang dalam hal ini adalah penyelenggaraan e-government di Kabupaten Bandung. Kemudian, peneliti berusaha untuk menganalisisnya dengan menggunakan teori dan konsep e-government yang terdiri dari tiga element yaitu : support, capacity dan value yang berkaitan dengan fenomena yang sedang diteliti. Sedangkan jenis penelitian yang digunakan adalah deskriptif, karena peneliti juga ingin menganalisis dan menjelaskan fenomena penyelenggaraan e-government di Kabupaten Bandung secara lugas dan jelas. Dalam pengumpulan data, teknik yang digunakan adalah studi literatur. Studi literatur ini bersumber dari sejumlah artikel dalam jurnal, buku, peraturanperaturan, konten media informasi yang berkaitan dengan fokus dan isu penelitian.

\section{Hasil dan Pembahasan}

Perkembangan Teknologi Informasi Komunikasi /TIK kita ketahui dizaman sekarang semakin berkembang pesat yang sudah menjadi suatu kebutuhan pokok/utama bagi setiap bidang kehidupan yang dilakukan manusia(Hermana \& Silfianti, 2011). Dalam perkrembangan teknologi tersebut tentu menjadi perhatian Pemerintah Kabupaten Bandung untuk menggunakan teknologi yang dimanfaatkan demi kemajuan teknologi informasi dalam penyelenggaraan pemerintahan di Kabupaten Bandung sebagai upaya dalam meningkatkan kualitas layanan publik yang lebih efektif dan efisien melalui penyelenggaraan e-government. Berdasarkan Peraturan Bupati Bandung Nomor 16 Tahun 2016 yang mengatur tentang Kebijakan Umum Penyelenggaraan EGovernment Di Lingkungan Pemerintah Kabupaten Bandung memiliki komponen penyelenggaraan e-Government yang meliputi: Aplikasi, Data Informasi, Infrastruktur, Kelembagaan; dan Sumber Daya Manusia TIK.

Menurut (Indrajit, 2004) ada tiga elemen untuk menerapkan konsep e-government yaitu: Pertama elemen support yang mana penyelenggaraan e-govermrnt perlu dukungan dari pejabat publik. Kedua elemen Capacity yang merupakan Sumber daya yang dibutuhkan dalam penyelenggaraan e-government baik sumber daya finansial dengan pembangunan infrastruktur dan sumber daya manusia. Ketiga Value yang merupakan nilai kebermanfaatan yang dipatkan oleh pemerintah dan masyarakat publik. 


\section{Elemen Support}

Dalam penerapan e-government di Kabupaten Bandung tentunya di dukung oleh pemerintah setempat dengan memberikan kewenangan khusus untuk lembaga yang bertanggung kawab dalam mengelola e-gverment di Kabupaten Bandung. Secara kelembagaan penyelenggaraan e-government di Kabupaten Bandung dikelola oleh Badan Arsip Perpustakaan dan Pengembangan Sistem Informasi (BAPAPSI) yang meanggungjawabi beberapa hal seperti halnya : pengelolaan aplikasi website, pelayanan publik dan manajerial pemerintahan. Adapun dalam Bidang Pengelolaan dan Pengembangan Informasi memiliki tugas yakni : memimpin, koordinasi dan pengendalian setiap tugas dalam hal pengelolaan layanan dan pengembangan informasi baik mencangkup sarana komunikasi, informasi dan diseminasi pengelolaan sistem informasi serta telematika. Sedangkan di Bidang Pemberdayaan Informasi memiliki tugas untuk memimpin, berkoordinasi danpengendalian setiap bidang pelayanan pemberdayaan informasi yang meliputi pemberdayaan informasi grafika, elektronika dan pemberdayaan informasi luar ruang (Bapapsi Kabupaten Bandung, 2020).

Adapun Mekanisme Pelayanan Informasi Publik Badan Arsip Perpustakaan dan Pengembangan Sistem Informasi (BAPAPSI) Kabupaten Bandung dapat dilihat sebagai berikut :

\section{Gambar 1}

\section{Mekanisme Pelayanan Informasi}

\begin{tabular}{|c|c|c|c|c|c|c|}
\hline \multicolumn{7}{|c|}{ MEKANISME PELAYANAN INFORMASI PUBLIK } \\
\hline \multirow{2}{*}{ No. } & \multirow{2}{*}{ URALAN KEGLATAN } & \multicolumn{2}{|c|}{ PELAKSANA } & \multicolumn{3}{|c|}{ MUTU BAKU } \\
\hline & & PEMOHON & PPID & PERSYARATAN/KELENGKAPAN & WAKTU & OUTPUT \\
\hline 1 & Pengajuan Permohanan informasi Pubilik & & & & & \\
\hline 2 & Pencatatan Permohonan Irformasi Publik & & & $\begin{array}{l}\text { Formulir Permohonan hlormasi Publik } \\
\text { (Lampiran il) }\end{array}$ & 1 Hain & $\begin{array}{l}\text { - Tanda Terma Permohonan informasi Pudilik } \\
\text { (Lampiran if); } \\
\text { Register Permahonan normasi Publik } \\
\text { (Lampiran ili) }\end{array}$ \\
\hline 3 & $\begin{array}{l}\text { Menernukan apakah inbormasi yang dimints } \\
\text { diluasai atau bdak? }\end{array}$ & & & $\begin{array}{l}\text { Formulit Permohonan hoormasi Publik } \\
\text { (Lampiran ii) }\end{array}$ & & Hasil pencarian inbormasi \\
\hline 4 & $\begin{array}{l}\text { Merertukan apakah inbormasi yang diminta } \\
\text { temasuk dalam Daftar nlormasi Pubilik asu } \\
\text { Tidak? }\end{array}$ & & & $\begin{array}{l}\text { Formulir Permohonan informasi Publik } \\
\text { (Lampiran il) } \\
\text { Daftar hormasi Publik } \\
\text { (Lampiran I) }\end{array}$ & 2 Hair & Hasil pencarian informasi \\
\hline 5 & $\begin{array}{l}\text { Merentukan apakah inbormasi yang diminta } \\
\text { Termasuk informasi yang dikecualikan atsu } \\
\text { Tidak? }\end{array}$ & & & $\begin{array}{l}\text { - Formulir Permohonan hlormasi Publik } \\
\text { (Lampiran if) } \\
\text { - Perauran Peundang-undangan verkait }\end{array}$ & $\begin{array}{c}5 \text { Hai } \\
\text { (Dapatditambaht } \\
7 \text { hasri apabila } \\
\text { dipertlukan) }\end{array}$ & Hasil Uj Konsekwensi \\
\hline 6 & Pembuatan Pemberitahuan Tertulis & & & $\begin{array}{l}\text { - Hasil pencarian inbrmasi danatau; } \\
\text { - Hasil Uji Konsekwensi }\end{array}$ & 1 Hahi & $\begin{array}{l}\text { Pemberitahuan Terulis } \\
\text { (Lampiran N) }\end{array}$ \\
\hline 7 & Penyampaian Penberitaisuan Tertulis & & & $\begin{array}{l}\text { Pemberitahuan Terulis } \\
(\text { Lampiran } \mathrm{V} \text { ) }\end{array}$ & 1 Hair & \begin{tabular}{|l} 
Pemberitithuan Terulis \\
(Lampian $N$ )
\end{tabular} \\
\hline 8 & Pembuatan Pendakan & & & $\begin{array}{l}\text { - Hasil pencarian informasi danvatau; } \\
\text { - Hasil Uji Kansekwensi }\end{array}$ & 1 Han & \begin{tabular}{|l} 
Penolakan \\
(Lampiran V)
\end{tabular} \\
\hline 9 & Penyampaian Perolakan & & & \begin{tabular}{|l|} 
Penolakan \\
(Lampiran V)
\end{tabular} & 1 Hani & $\begin{array}{l}\text { Penolakan } \\
\text { (Lampiran V) }\end{array}$ \\
\hline 10 & $\begin{array}{l}\text { Penyampaian Sxinan Dokumen Informasi } \\
\text { Publik }\end{array}$ & & & Salinan Dokumen nlormasi Publik & 1 Hain & $\begin{array}{l}\text { - Salinan Dokumen Informasi Pubilik } \\
\text { Tanda Terima Salinan Ddkumen Irfamas } \\
\text { Publik }\end{array}$ \\
\hline 11 & Selesa & & & & & \\
\hline
\end{tabular}

Sumber: BAPAPSI Kabupaten Bandung (2016)

Berdasarkan hal si atas, secara kelembagaan penyelenggaraan e-government di Kabupaten Bandung memiliki komponen yang mempuni dilihat dari tugas dan tanggung jawab yang jelas serta mekanisme pelayanan publik yang di selenggarakan Badan Arsip Perpustakaan dan Pengembangan Sistem Informasi (BAPAPSI) Kabupaten Bandung sebagai kelembagaan penyelenggaraan e-government. Badan Perpustakaan, Arsip dan Pengembangan Sistem Informasi (BAPAPSI) pada tahun sebelumnya menjalankan tiga tanggungjawab yang harus diurus yakni; urusan dakam hal kearsipan, urusan dalam hal komunikasi dan Informatika serta urusan dalam hal perpustakaan. Namun setelah diterbitkannya Peraturan Daerah Nomor 12 
Tahun 2016 tentang Pembentukan dan Susunan Perangkat Daerah Kabupaten Bandung maka pada tahun 2017 dalam urusan kearsipan dan perpustakaan menjadi kewenangan Dinas Perpustakaan dan Kearsipan (DISPUSIP), sedangkan dalam urusan pengelolaan komunikasi publik, informatika, statistik dan persandian merupakan kewenangan dari Dinas Komunikasi dan komunikasi (DISKOMINFO). (LKIP DISKOMINFO Kab.Bandung, 2016).

Dalam hal ini penyelenggaraan e-government di suatu pemerintah daerah tentu memerlukan badan atau lembaga khusus yang bertanggung jawab dan menjalankan tugasnya dalam mengelola e-government. Lembaga penyelenggaraan pemerintah di Kabupaten Bandung sendiri tahun ke tahun mengalami perubahan yang dulu dikelola oleh BAPAPSI sekarang dikelola oleh DISKOMINFo, hal ini menandakan perlunya fokus dalam bidang teknologi informasi sehingga tidak terjadi nya tumpang tindih dalam menjalankan tugas serta terarah dalam mencapainya, hal ini menjadi suatu terobosan yang diambil Pemerintah Daerah Kabupaten Bandung yang menandakan keseriusan dalam menyelenggarakan e-government sebagai upaya meningkatkan kualitas pelayanan publik di wilayah Kabupaten Bandung.

\section{Elemen Capacity}

Dalam penerapan penyelenggaraan e-government tentu memiliki Sumberdaya yang dimiliki untuk membantu menyelenggarakan e-government agar dapat dijalankan dengan baik baik sumberdaya finansial dengan pembangunan infrastruktur ataupun sumber daya manusia(Angguna, 2015). di Kabupaten Bandung tentu memiliki sumberdaya yang ada untuk menopang penyelenggaraan e-government, yang sesuai dengan kapasitas yang dimiliki oleh pemerintah setempat.

\section{Sumberdaya Infrastruktur}

Infrastruktur merupakan salahsatu komponen yang menjadi pendukung untuk menciptakan lingkungan yang kondusif untuk pengembangan dan penyelenggaraan egovernment. Tersedianya infrastruktur bagi keberlangsungan pelayanan bagi masyrakat bebasis elektroik dengan memanfaatakan teknologi digital juga menjadi sebuah strategi untuk mendapat respon baik dari masyarakat dan dunia usaha ataupun pihak lainnya untuk membangun suatu kerjsama yang dilakukan dengan pemerintah, hal tersebut tentu perlunya pengembangan infrastruktur yang lebih baik sehingga pihak yang bekerja sama akan merasa tertarik serta adanya keamanan dan kepastian terhadap infrastruktur yang dipergunakan untuk menunjang kerjasama sehingga tidak akan menimbulkan kergauan untuk berpartisipasi dan berinvestasi di sektor publik (Nugraha, 2018).

Penerapan e-government dalam pelayanan publik di Kabupaten Bandung belum berjalan secara masif, karena beberapa faktor seperti halnya faktor wilayah yang dikategorikan sebagai daerah rural/pedesaan dimana terdiri dari 31 kecamatan dan kondisinya cenderung memiliki ruang geografis berupa perbukitan, hutan, serta hamparan sawah dan ladang yang memerlukan infrastruktur telekomunikasi, ditengah-tengah penyebaran penduduk yang terletak saling berjauhan satu sama lain. Kepala BAPAPSI Kabupaten Bandung, Tri Heru Setiati,mengatakan bahwa dalam pelaksanaan penyelenggaraan pemerintahan berbasis online ternyata masih ditemui beberapa kendala. Sepertihalnya belum infrastruktur telekomunikasi yang belum memadai di beberapa kecamatan seperti: Rancabali, Kertasari, Pacet dan Kecamatan Arjasari. Adanya kendal ketersediaan prasarana telekomunikasi pelayanan publik di Kabupaten Bandung menjadi terhambat oleh buruknya sinyal telekomunikasi yang ada (Sukarno, 2017). 
Berdasarkan data Bappeda Kabupaten Bandung yang menjelaskan bahwa pada tahun 2010-2015, masih rendahnya ketersediaan di bidang teknologi yang merupakan salahsatu sarana yang menunjang dalam terselenggaranya pelayanan publik di Kabupaten Bandung, walupun demikian dari tahun ke tahun ada peningkatan, hal ini dijelaskan pada tabel berikut:

Tabel 1.

Daftar Ketersediaan Sarana/Prasarana (Teknologi) Komunikasi Dan Informasi di Kabupaten Bandung Tahun 2010 - 2015

\begin{tabular}{|c|c|c|c|c|c|c|c|}
\hline No. & $\begin{array}{c}\text { Sarana/Prasarana } \\
\text { (Teknologi) Komunikasi Dan } \\
\text { Informasi }\end{array}$ & 2010 & 2011 & 2012 & 2013 & 2014 & 2015 \\
\hline 1. & $\begin{array}{l}\text { Jumlah Perangkat Daerah Yang } \\
\text { Memiliki Akses Internet }\end{array}$ & 100 & 28 & 28 & 72 & 72 & 72 \\
\hline 2. & $\begin{array}{l}\text { Jumlah Sistem Informasi yang } \\
\text { Ada }\end{array}$ & 38 & 38 & 38 & 38 & 38 & 61 \\
\hline 3. & $\begin{array}{l}\text { Jumlah Titik Hotspot Yang } \\
\text { Difasilitasi Pemerintah Daerah }\end{array}$ & 5 & 5 & 5 & 5 & 5 & 5 \\
\hline
\end{tabular}

Sumber: Bappeda Kabupaten Bandung (2016)

Pada tabel tersebut, bisi diketahui berkaitan dengan jumlah akses jaringan internet yang merupakan fasilitasi dari pemerintah daerah Kabupaten Bandung yang diperuntukan untuk masyarakatna memiliki jumlah sebanyak 5 titik. Hal tersebut apabila dibandingkan dengan luas keseluruhan wilayah dan rasio jumlah penduduk yang berada di wilayah Kabupaten Bandung, maka belum dapat terpenuhi. sepenuhnya tingkat kapasitas organisasi di kecamatan yang akan berdampak pada peningkatan kualitas pelayanan masyarakat. Berkenaan infrastruktur baik ketersediaan sarana/prasarana dalam menunjang penyelenggaraan e-government merupakan hal yang penting, terutama berkaitan dengan tingkat penyebaran dan pemerataan infrastruktur di tiap daerah, agar terselenggaranya pelayanan publik yang adil dengan dukungan infrastruktur yang sama-sama memadai ditiap daerah (Mariano, 2019).

Keterbatasan infrastruktur tersebut, tidak menjadi halangan untuk tetap mengoptimalkan dalam penyelenggaraan e-government dengan sumber daya yang ada, karena pembangunan infrastruktur dilakukan oleh pemerintah Kabupaten Bandung secara bertahap, mengingat masyarakat di Kabupaten Bandung yang notabene sebagai masyarakat pengguna teknologi yang belum begitu masif seperti halnya Kota Bandung, yang merupakan daerah dengan kondisi masyarakat yang beragam di dukung dengan kemajuan teknologi yang ada.

\section{Sumber Daya Manusia}

Ketersediaan sumber daya manusia yang dimiliki, tentu harus memiliki kemampuan/keahlian dan kompetensi yang mempuni, yang tentunya sangat perlukan dalam penyelenggaraan e-government, sehingga dapat sesuai dengan yang diharapkan (Nugraha, 2018). Ketersediaan sumber daya manusia yang menguasai teknologi informasi masih menjadi tantangan bagi Pemerintah Kabupaten Bandung, dalam menyelenggarakan e-government kualitas sumber daya manusia juga ikut mempengaruhi karena SDM sebagai user/pengguna teknologi yang dirasa belum secara keseluruhan mampu dan memahami dalam mengoperasikannya.

Seperti yang dikatakan Kepala BAPAPSI Kabupaten Bandung, Tri Heru Setiati dimana terdapat beberapa kendala yang ditemui dalam penyelenggaraan e-government yang berkaitan dengan sumber daya TIK seperti halnya untuk beberapa aplikasi layanan publik belum terintegrasi dan juga faktor sumber daya manusia di bidang TIK yang bisa dikatakan belum 
optimal. Permasalahan lainnya pada Sumber Daya Manusia (SDM) yaitu pada masyarakat pengguna atau pengakses teknologi itu sendiri, dimana penggunan akses Internet di Kabupaten Bandung yang lebih rendah dibandingkan dengan daerah lain seperti Kota Bandung, Cimahi dan kota-kota besar lainnya.

Salah satu contohnya adalah dalam penggunaan media sosial, sebagai sarana komunikasi dan interaksi masyarakat yang masih terbilang masih rendah. Dimana Badan Perpustakaan Arsip dan Pengembangan Sistem Informasi (BAPAPSI) pernah membuat akun twitter sebagai salahsatu sarana interaksi masyarakat dan pemerintah dalam memberikan saran atau respon terhadap Kabupaten Bandung, namu ternyata penggunanya masih relatif sedikit (Bandung.Bisnis.com, 2015).

Masih terbatasnya sumberdaya yang mempuni dibidang teknologi dan informasi yang merupakan sebuah bidang yang banyak diminati dan berkembang pesat. Pada umumnya sumberdaya manusia untuk bidang teknologi dan informasi banyak dimiliki oleh pihak pembisnis atau industri. Pemerintah harus mempersiapkan SDM yang mempunyai kapasitas baik dari pengetahuan tentang teknologi, manjerial dan penguasaan teknologi yang menjadi modal utama untuk menyelenggrakan e-government (Nurhakim, 2014).

\section{Elemen Value}

\section{Pemanfaatan Penggunaan Aplikasi}

Penyelenggaraa e-government tentu tidak lepas dari aplikasi yang digunakan sebagai wadah interaksi bagi setiap pengguna layanan publik berbasis digital. Konsep e-government yang kian berkembang tidak hanya berbasis pada komputer dalam melakukan manajerial dan pengembangan sistem informasi, namun konsep e-government yang sudah berkembang pesat pada masa sekarang lebih mengarah pada terintegrasinya data dan informasi antar lembaga pemerintahan melalui bantuan akses internet dengan menggunakan perangkat lunak yang merupakan program yang dibuat sebagai perkembangan teknologi yang lebih canggih serta dengan menggunakan bahasa pemrograman yang mendukung teknologi yang lebih baik, maka penyelenggaraan e-government berkembang dalam pembuatan website oleh lembaga pemerintah (Nurhakim, 2014). Berikut merupakan salah satu website pemerintah Kabupaten Bandung sebagai bentuk penyelenggaraan e-government dalam meningkatkan pelayanan publik :

\section{Gambar 2}

\section{Website Pemerintah Kabupatn Bandung}

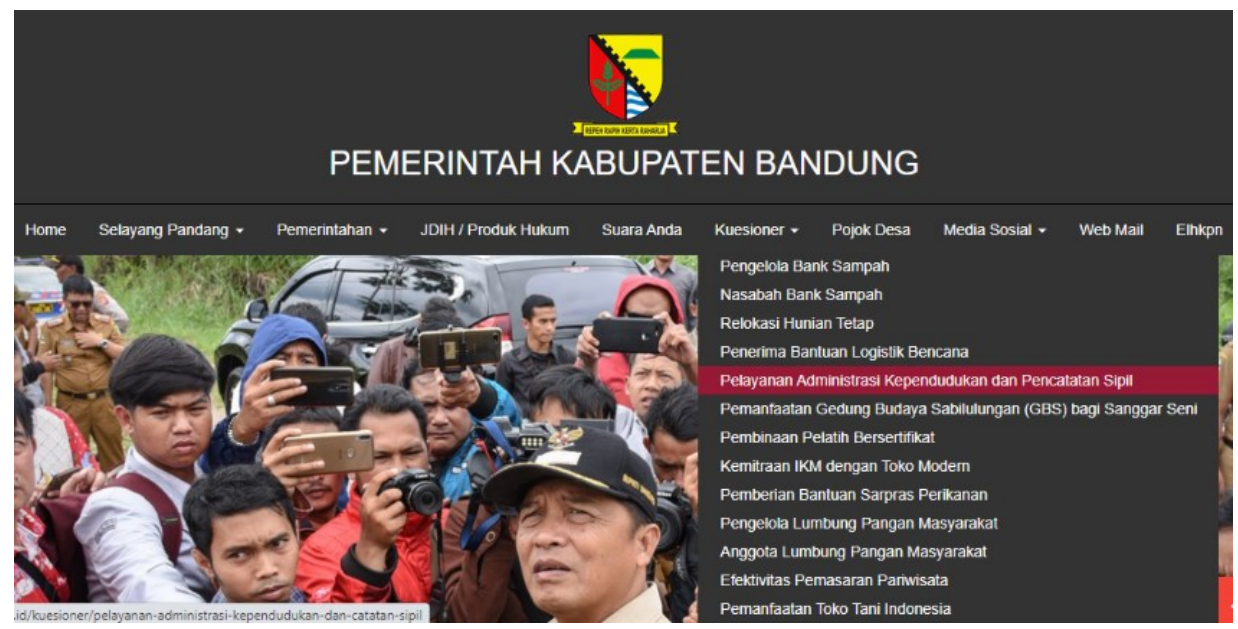

Sumber: bandungkab.go.id (2020) 
Selain itu, menurut Asisten Administrasi Setda Kabupaten Bandung, Diar Irwana mengatakan bahwa pemanfaatan TIK dalam beberapa pelaksanaan suatu kegiatan di Kabupaten Bandung sudah dilakukan berbasis elektronik dan digitalisasi yang menggunakan akses internet sebagai daya dukungnya, seperti dalam pembangunan dan pengembangan jaringan komunikasi data di Kabupaten Bandung dalam membantu mengkoneksikan semua Organisasi Perangkat Daerah/ OPD untuk menjalankan suatu aplikasi sistem informasi manajemen daerah dan keuangan yang dikenal dengan nama aplikasi SIMDA, selain itu penerapan berbasis teknologi juga diterapkan dalam bentuk daftar hadir pegawai berbasis online atau yang dikenal dengan aplikasi SIMPEG.

Adapun aplikasi lainnya dalam memberikan pelayanan publik, salah satunya adalah pelayanan yang dilakukan di Rumah Sakit (RS) dimana dengan menerapkannya aplikasi sistem informasi manajemen yang kenal dengan aplikasi SIM , dimana aplikasi tersebut ang sudah terintegrasi dengan Badan Penyelenggara Jaminan Sosial/ BPJS, kemudian selain itu adanya aplikasi SIM Puskesmas, Aplikasi PB Online, Aplikasi SIM Perizinan, dan sisten informasi manajemen kecamatan yang dikenal dengan nama aplikasi SiMacan. Adapun dilihat dari aplikasi lainnya yakni dalam Manajemen Kepemerintahan, program kegiatan yang sudah dilakukan diantaranya mencakup Rencana Kerja Pemerintah Daerah/ RKPD berbasis online, aplikasi eMonev, aplikasi SIMDA Barang dan dan Jaringan Dokumentasi dan Informasi Hukum atau yang dikenal dengan aplikasi JDIH.

Dilihat dari sisi aplikasi dalam penyelenggaraan e-government Kabupaten Bandung sudah mempuni,dimana terdapat beberapa aplikasi yang mendukung penyelenggaraan di Kabupaten Bandung sebagai upaya dalam memberikan pelayanan yang lebih baik bagi masyarakat di Kabupaten Bandung, hal ini tentu menjadi aset pendukung yang dimiliki pemerintah setempat untuk mampu menglola dengan baik agar maksimal dalam menyelenggarakan e-government di pemerintah daerah.

\section{Pemanfaatan Data Informasi}

Penyelenggaraan e-government tentunya data informasi menjadi hal penting yang harus diperhatikan, artinya kemudahan dalam mendapatkan data berbasis online bagi publik. Pemerintah Kabupaten Bandung memiliki data informasi yang dimuat dalam open data dan dapat diakses di website sistem informasi manajemen statistik daerah (SI-MASDA), sebagai portal satu data Kabupaten Bandung dalam menunjang penyelenggaraaan e-government. Berikut merupakan gambar web dari portal satu data Kabupaten Bandung: 


\section{Gambar 3}

Portal satu data Pemerintah Kabupatn Bandung

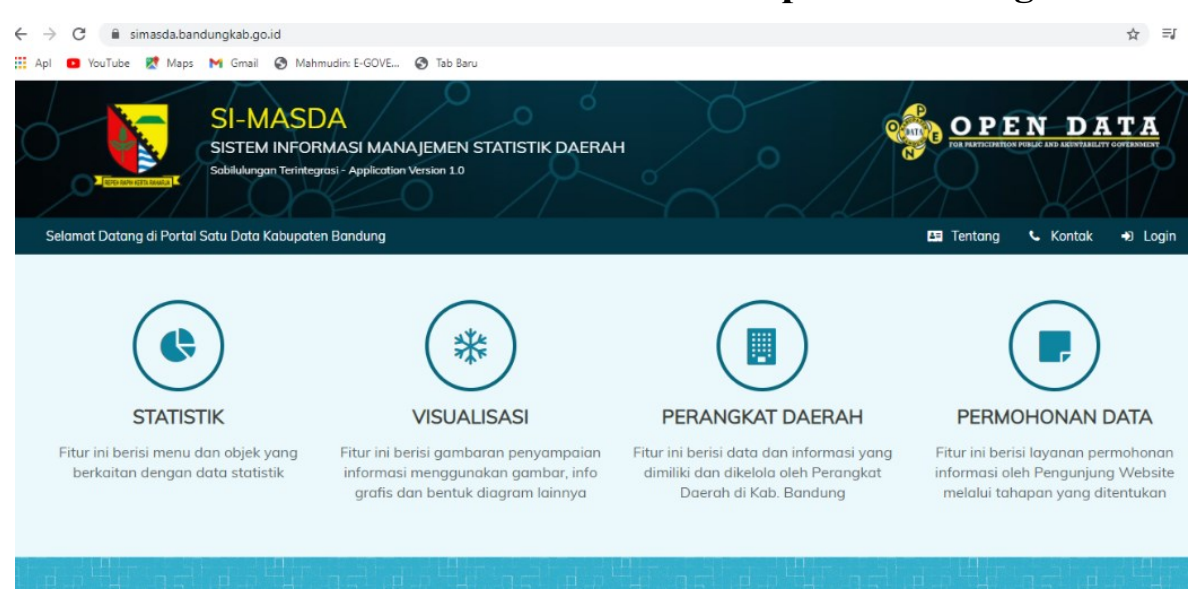

Sumber: simasda.bandungkab.go.id/ (2020)

Portal diatas merupakan wadah untuk mengakses informasi yang diperlukan oleh publik, dalam hal ini secara data informasi Kabupaten Bandung sudah mulai berkembang lebih baik, dimana data yang diperlukan tidak hanya di arsipkan dalam bentuk kertas melainkan juga disimpan di aplikasi virtual yang bisa di akses publik dengan online, walau demikian belum sepenuhnya data informasi yang diperlukan bisa di dapat di portal tersebut, hal tersebut tentu perlu bertahap dan memilah data-data yang tentunya bisa di akses oleh publik. Yang terpenting adalah dengan adanya portal satu data ini sebagai angkah mengembangkan dan mendukung dalan penyelenggaraan e-government di Kabupaten Bandung, yang mana e-government tidak terlepas dari prinsip transparansi publik yang merupakan suatu keterbukaan secara sungguh-sungguh, menyeluru ke semua lapisan masyarakat dalam proses pengelolaan sumber daya publik. Karena dalam pelaksanaanya akuntabilitas dan transfaransi merupakan konsep dari e-government dalam mewujudan good governance, namun dalam pelaksanaan akuntabilitas tidak bisa lepas dari pelaksanaan transparansi (Sa'adah, 2015).

Keberadaan data informasi menjadi hal yang amat penting, karena pengelolaan data dan kearsipan dalam penyelenggaraan e-government harus mudah didapatkan yang diakses oleh publik, yang tentunya data informasi ini mengacu pada Big Data yang menghimpun keseluruhan data-data yang diperlukan untuk memudahkan pelayan publik(Irawan, 2017). Hal tersebut dapat memudahkan baik pihak pemerintah dalam pengelola aplikasi agar data yang dimiliki bisa disimpan dan di integrasikan ke aplikasi lainnya yang memiiki keterikatan dengan data yang diperlukan, serta memudahkan masyarakat untuk mengakses dan mendapatkan data yang diperlukan melalui layanan aplikasi yang disediakan pemerintah Kabupaten Bandung.

Dari pemaparan diatas bisa dipahami dari hasil penelitian ini menunjukkan bahwa penyelenggaraan e-government di Kabupaten Bandung masih dalam tahap perkembangan yang sifatnya belum begitu masif, hal ini dilihat dari keterbatasan infrastruktur penunjang teknologi dan kualitas sumberdaya dibidang teknologi yang masih kurang, namun demikian sudah diterapkan sesuai dengan kapasitas dan kemampuan intansi terkait, dan mengacu pada peraturan yang memuat tentang e-government, meski belum maksimal dalam pelaksanaanya dan dampak yang signifikan dirasakan oleh publik, Pemerintah Kabupaten Bandung sudah mulai berkembang secara bertahap dari sebelumnya. 


\section{Simpulan}

Penyelenggraan e-government di Kabupaten Bandung tidak akan terlepas elemen sebagai komponen pendukung e-government itu sendiri. Dilihat dari elemen support, memiliki dukungan dari pejabat pemerintah di Kabupaten Bandung untuk menerapkan penyelenggaraan egovernment dengan diberikan tugas khusus kepada Diskominfo. Sedangkan pada elemen Capacity, dari sisi infrastruktur memang Kabupaten Bandung masih mengalami kekurangan saran dan prasarana dalam penyelenggaraan e-government untuk melayanan publik namun tetap memaksimalkan pembangunan infrastruktur yang dilakukan bertahap. Sedangkan dari sisi sumber daya manusia di Kabupaten Bandung yang masih kurang di bidang teknologi informasi dan komunikasi, artinya masih rendahnya penguasaan terhadap teknilogi informasi, yang tentu menjadi perhatian yang harus dibenahi untuk kedepannya bisa memaksimalkan penyelenggaraan e-government di Kabupaten Bandung yang lebih unggul. Terakhir padal elemen value yang terdiri dari pemanfaatan aplikasi, Kabupaten Bandung sudah menerapkan beberapa aplikasi berbasis internet dalam menunjang pelayanan publik, demikian juga dari komponen data informasi telah disediakan portal satu data untuk memberikan akses kepada publik untuk memperoleh data yang diinginkan walaupun belum semua data tersedia. Adapun rekomendasi kedepannya untuk meningkatkan kualitas e-government di Kabupaten Bandung perlu ditingkatkan dalam segi infrastruktur yang ada agar sarana dan prasarana teknologi dapat mempuni dan ditingkatkannya kualitas sumber daya manusia yang ada salahsatunya pelatihan/workshop/ bimbingan teknis dalam penggunaan teknologi informasi.

\section{Referensi}

Angguna, Y. (2015). Upaya Pengembangan E-Government Dalam Pelayanan Publik Pada Dinas Koperasi Dan UKM Kota Malang. Jurnal Administrasi Publik Mahasiswa Universitas Brawijaya, 3(1), 80-88.

Aprianty, D. R. (2016). Penerapan Kebijakan E-Government dalam Peningkatan Mutu Pelayanan Publik di Kantor Kecamatan Sambutan Kota Samarinda. Jurnal Ilmu Pemerintahan, volume 4(4), hlm. 1593.

Bandung.Bisnis.com. (2015). Mayoritas Warga Kabupaten Bandung Buta Internet. https://bandung.bisnis.com/read/20150901/549/1074476/mayoritas-warga-kabupatenbandung-buta-internet

bandungkab.go.id. (2016). E-Gov Tingkatkan Kualitas Pelayanan Pemerintah Kepada Publik. http://www.bandungkab.go.id/arsip/e-gov-tingkatkan-kualitas-pelayanan-pemerintahkepada-publik

Bapapsi Kabupaten Bandung. (2020). Tupoksi Badan Perpustakaan, Arsip dan Pengembangan Sistem Informasi. https://bapapsi1.wordpress.com/tupoksi/

Hermana, B., \& Silfianti, W. (2011). Evaluating e-government implementation by local government: digital divide in internet based public services in Indonesia. International Journal of Business and Social ..., 2(3), 156-164. http://ijbssnet.com/journals/Vol.2__No._3_[Special_Issue_-_January_2011]/18.pdf

Heryana, T. (2013). Pengaruh Penerapan E-Government Terhadap Pelaksanaan Tata Kelola Pemerintah Di Pemerintah Kabupaten Cianjur. Jurnal Riset Akuntansi Dan Keuangan, 1(1), 38. https://doi.org/10.17509/jrak.v1i1.6572

Indrajit, R. E. (2004). Elektronic Goverment (e-Gov) Strategi Pembangunan dan Pengembangan Sistem Pelayanan Publik Berbasis Teknologi Digital. Andi. 
Indonesia, P. R. (2003). Instruksi Presiden Republik Indonesia Nomor 3 Tahun 2003 tentang Kebijakan dan Strategi Nasional Pengembangan E-Government. Jakarta: Sekretaris Negara.

Irawan, B. (2017). Studi Analisis Konsep E-Government: Sebuah Paradigma Baru dalam Pelayanan Publik. Jurnal Paradigma (JP), 2(1), 174-201.

LKIP DISKOMINFO Kab.Bandung. (2016). Laporan Kinerja Instansi Pemerintah DISKOMINFO Kabupaten Bandung. https://www.bandungkab.go.id/uploads/20170412011829-1kip-diskominfo-2016.pdf

mariano, sabino. (2019). Penerapan E-Government Dalam Pelayanan Publik Di Kabupaten Sidoarjo. Journal of Chemical Information and Modeling, 53(9), 1689-1699.

Napitupulu, D. (2015). Kajian Faktor Sukses Implementasi E-Government, Studi Kasus: Pemerintah Kota Bogor. SISFO, 5.

Nugraha, J. T. (2018). E-Government Dan Pelayanan Publik (Studi Tentang Elemen Sukses Pengembangan E-Government Di Pemerintah Kabupaten Sleman). Jurnal Komunikasi Dan Kajian Media, 2(1), 32-42.

Nurhakim, M. R. S. (2014). Implementasi E-Government Dalam Mewujudkan Transparansi Dan Akuntabilitas Sistem Pemerintahan Modern. Jurnal Ilmu Administrasi Media Pengembangan Dan Praktik Administrasi, 9(3), 403-422.

Oktari, R., \& Nasir, A. (2011). Pengaruh Pemanfaatan Teknologi Informasi Dan Pengendalian Intern Terhadap Kinerja Instansi Pemerintah ( Studi Pada Satuan Kerja Perangkat Daerah Kabupaten Kampar ). Jurnal Ekonomi Universitas Riau, 19(02), 8841.

Praditya, D. (2014). Pemanfaatan teknologi informasi dan komunikasi (TIK) di tingkat pemerintahan desa. Jurnal Penelitian Komunikasi, 17(2), 129-140.

Sa'adah, B. (2015). Akuntabilitas dan Transparansi Anggaran Melalui e-Government. Kebijakan Dan Manajemen Publik Volume, 3(2), 1-10.

Sari, K. D. A., \& Winarno, W. A. (2012). Implementasi E-government System Dalam Upaya Peningkatan Clean And Good Goverment Di Indonesia. Jeam, XI(1), 1-19.

Sukarno, D. (2017). Infrastruktur dan Teknologi Pada Kecamatan-Kecamatan di Kabupaten Bandung Dalam Mendukung Pelaksanaan Program Paten (Pelayanan Administrasi Terpadu Kecamatan). Jurnal Manajemen Pelayanan Publik, $1(1), \quad 109$. https://doi.org/10.24198/jmpp.v1i1.13565 